\title{
Pengaruh Etos Kerja Dan Disiplin Kerja Terhadap Kinerja Pegawai Pada Dinas Kehutanan Dan Perkebunan Kota Bogor
}

\author{
${ }^{1}$ Nurjaya, ${ }^{2}$ Denok Sunarsi, ${ }^{3}$ Aidil Amin Effendy, ${ }^{4}$ Arga Teriyan, ${ }^{5}$ Gunartin \\ ${ }^{1}$ Universitas Suryakancana. Cianjur, Jawa Barat, Indonesia \\ ${ }^{2.3 .4}$ Universitas Pamulang, Tangerang Selatan, Banten, Indonesia \\ Email: $\underline{\text { nurjaya@unsur.ac.id }}$
}

(Diterima: Nov 2020; Direvisi: Des 2020; Dipublikasikan: Jan 2021)

\begin{abstract}
ABSTRAK
Penelitian ini bertujuan untuk mengetahui pengaruh etos kerja dan disiplin kerja terhadap kinerja pegawai pada Dinas Kehutanan dan Perkebunan Kota Bogor. Metode yang digunakan adalah explanatory research dengan teknik analisis menggunakan analisis statistik dengan pengujian regresi, korelasi, determinasi dan uji hipotesis. Hasil penelitian ini etos kerja berpengaruh signifikan terhadap kinerja pegawai sebesar $43,1 \%$, uji hipotesis diperoleh $t$ hitung $>\mathrm{t}$ tabel atau $(6,628>$ 2,002). Disiplin kerja berpengaruh signifikan terhadap kinerja pegawai sebesar $40,7 \%$, uji hipotesis diperoleh t hitung $>\mathrm{t}$ tabel atau $(6,311>2,002)$. Etos kerja dan disiplin kerja secara simultan berpengaruh signifikan terhadap kinerja pegawai dengan persamaan regresi $\mathrm{Y}=9,939+0,395 \mathrm{X} 1+0,360 \mathrm{X} 2$. Kontribusi pengaruh sebesar 53,0\%, uji hipotesis diperoleh $\mathrm{F}$ hitung > F tabel atau $(32,194>2,770)$.
\end{abstract}

Kata Kunci: Etos Kerja, Disiplin Kerja, Kinerja Pegawai. 


\section{PENDAHULUAN}

Salah satu upaya instansi dalam mempertahankan kinerja pegawainya adalah dengan cara memperhatikan motivasi dan etos kerja pegawai yang merupakan salah satu faktor penting untuk mendapatkan hasil kerja yang optimal. Pegawai merupakan aset penting dalam suatu instansi, tanpa mereka betapa sulitnya instansi mencapai tujuan, merekalah yang menentukan maju mundurnya suatu instansi, dengan memiliki tenagatenaga kerja yang terampil dengan motivasi tinggi instansi telah mempunyai asset yang sangat mahal, sebab pada dasarnya manusia merupakan subyek dan obyek pembangunan yang merupakan faktor yang sangat penting, terutama peningkatan kualitas sumber daya manusia menjadi prioritas yang utama.

Kinerja merupakan hal penting yang harus dicapai oleh setiap instansi termasuk pada Dinas Kehutanan dan Perkebunan Kota Bogor, karena kinerja merupakan cerminan bagi kemampuan instansi dalam mengelola dan mengalokasikan pegawainya, oleh karena itu kinerja para pegawai mempunyai pengaruh yang sangat penting bagi berlangsungnya kegiatan instansi dan berpengaruh bagi proses pencapaian tujuan instansi.

Dinas Kehutanan dan Perkebunan Kota Bogor merupakan suatu instansi yang melakukan pembinaan, pengawasan dan pelaksanaan pembangunan kehutanan dan perkebunan kepada masyarakat untuk wilayah Kota Bogor, dimana keberhasilan pelaksanaan tugas dan tanggung jawab dalam instansi tergantung pada kinerja para pegawai yang ada di instansi tersebut, pentingnya kinerja pegawai yang ada pada Dinas Kehutanan dan Perkebunan Kota Bogor sangat berpengaruh terhadap pelaksanaan tujuan instansi itu, yaitu untuk meningkatkan pelayanan terhadap para masyarakat terutama dalam proses pengawasan dan pembinaan terhadap pembangunan hutan.

Kedudukan dan peranan Pegawai Negeri Sipil sebagai unsur aparatur negara yang bertugas sebagai abdi masyarakat harus menyelenggarakan pelayanan secara adil kepada masyarakat dengan dilandasi kesetiaan dan ketaatan kepada Pancasila dan UndangUndang Dasar 1945. Untuk dapat melaksanakan tugas dengan baik, maka pembinaan pegawai diarahkan untuk meningkatkan kualitas sumber daya manusia agar memiliki sikap dan perilaku yang berintikan pengabdian, kejujuran, profesional, tanggung jawab, disiplin, etos kerja, komitmen organisasi serta wibawa sehingga dapat memberikan pelayanan sesuai tuntutan perkembangan masyarakat.

Menurut Sinamo (2011) etos kerja adalah seperangkat perilaku kerja positif yang berakar pada kerjasama yang kental, keyakinan yang fundamental, disertai komitmen yang total pada paradigma kerja yang integral. Etos kerja yang tinggi seyogyanya harus dimiliki oleh setiap pegewai karena setiap organisasi sangat membutuhkan kerja keras dan komitmen yang tinggi setiap pegawai, kalau tidak organisasi akan sulit berkembang, dan memenangkan persaingn dalam merebut pangsa pasarnya. Setiap organisasi yang selalu ingin maju, akan melibatkan anggota untuk kinerjanya, 
diantaranya setiap organisasi harus memiliki etos kerja. Individu atau kelompok masyrakat dapat dinyatakan memiliki etos kerja yang tinggi. Etos kerja yang dimiliki oleh seseorang atau kelompok masyarakat, akan menjadi sumber motivasi bagi perbuatannya.

Pegawai Dinas Kehutanan dan Perkebunan Kota Bogor dituntut memiliki kesadaran akan tanggung jawab mengenai semangat etos kerja dan motivasi hanya sebagian kecil dari pegawai yang melakukannya. Bahkan sesuai pengamatan terlihat para pegawai mulai bersikap acuh tah acuh terhadap tupoksi yang ada cenderung ke arah kapan di perintah pimpinan baru melaksanakan tugas sementara tupoksi yang ada mulai terabaikan.

Berdasarkan uraian di atas, maka penulis mengambil penelitian berujudl "Pengaruh Etos Kerja dan Disiplin Kerja Terhadap Kinerja Pegawai Pada Dinas Kehutanan dan Perkebunan Kota Bogor".

\section{TINJAUAN PUSTAKA}

\section{Etos Kerja}

Definisi etos kerja yaitu seperangkat perilaku kerja positif yang berakar pada kesadaran yang kental, keyakinan yang fundamental, disertai komitmen yang total pada paradigma kerja yang integral, dalam hal ini dijabarkan dalam 8 (delapan) indikator yakni kerja adalah rahmat, kerja adalah amanah, kerja adalah panggilan, kerja adalah aktualisasi, kerja adalah ibadah, kerja adalah kehormatan dan kerja adalah pelayanan.

\section{Disiplin Kerja}

Disiplin kerja adalah kesadaran dan kesedian seseorang menaati semua peraturan perusahaan dan norma-norma sosial yang berlaku, (Singodimedjo dalam Sutrisno 2009 :94). Konsep indikator dalam mengukur disiplin kerja dalam penelitian ini berfokus pada fenomena terjadi di lapangan. Permasalahan yang terjadi dilihat dari fakta dilapangan, berdasar pada indikator disiplin kerja menurut Soejono (1997:67). Konsep tersebut menyebutkan disiplin di ukur berdasarkan ketepatan waktu, menggunakan peralatan kantor dengan baik, tanggung jawab yang tinggi dan ketaatan terhadap aturan kantor.

\section{Kinerja Pegawai}

Kinerja adalah hasil kerja secara kualitas dan kuantitas yang dicapai oleh seorang pegawai dalam melaksanakan tugasnya sesuai dengan tanggung jawab yang diberikan kepadanya (Mangkunegara, 2009:67). Konsep penilaian kinerja yang digunakan Dinas Kehutanan dan Perkebunan Kota Bogor mengukur kualitas kerja dari ketepatan waktu penyampaian laporan harian sedangkan kuantitas kerja di ukur dengan melihat pelaksanaan tugas pokok dan tugas tambahan. Sejalan dengan teori dari Miner (Sudarmanto, 2009:11-12), yang dijadikan sebagai tolak ukur dalam menilai kinerja, yaitu: kuantitas, kualitas, penggunaan waktu dalam bekerja dan kerjasama dengan orang lain dalam bekerja. 


\section{Metode Penelitian}

Menurut pendapat Sugiyono (2016) "Model penelitian merupakan sintesa yang mencerminkan keterkaitan antara variabel yang diteliti dan merupakan tuntunan untuk memecahkan masalah penelitian serta merumuskan hipotesis yang berbentuk bagan alur yang dilengkapi penjelasan kualitatif". Dalam penelitian ini model penelitian yang dibuat sebagai berikut:

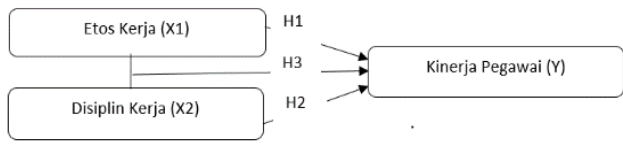

Gambar 1. Paradigma Model Penelitian

\section{Hipotesis Penelitian}

Hipotesis yang peneliti ajukan adalah sebagai berikut:

$\mathrm{H} 1$ :Diduga terdapat pengaruh yang signifikan antara etos kerja terhadap kinerja pegawai pada Dinas Kehutanan dan Perkebunan Kota Bogor.

$\mathrm{H} 2$ :Diduga terdapat pengaruh yang signifikan antara disiplin kerja terhadap kinerja pegawai pada Dinas Kehutanan dan Perkebunan Kota Bogor.

H3 :Diduga terdapat pengaruh yang signifikan antara etos kerja dan disiplin kerja secara simultan terhadap kinerja pegawai pada Dinas Kehutanan dan Perkebunan Kota Bogor.

\section{METODE PENELITIAN}

\section{Populasi}

Populasi dalam penelitian berjumlah 60 responden Dinas Kehutanan dan Perkebunan Kota Bogor

\section{Sampel}

Teknik pengambilan sampling dalam penelitian ini adalah samplel jenuh, dimana semua anggota populasi dijadikan sebagai sampel. Dengan demikian sampel dalam penelitian ini berjumlah 60 responden.

\section{Metode Analisis Data}

Jenis penelitian yang dipakai adalah asosiatif, dimana tujuannya adalah untuk mengetahui mencari keterhubungan antara Dalam menganalisis data digunakan uji instrumen, uji asumsi klasik, regresi, koefisien determinasi dan uji hipotesis.

\section{HASIL PENELITIAN}

\section{Uji Instrumen}

Pada pengujian ini digunakan uji validitas dan uji reliabilitas. Uji validitas dimaksudkan untuk mengetahui ketepatan data tentang kesesuaian antara yang mau diukur dengan hasil pengukurannya. Menurut Sugiyono (2016) "Valid berarti terdapat kesamaan antara data yang terkumpul dengan data yang sesungguhnya". Sedangkan Ghozali (2013) berpendapat "Suatu kuesioner dikatakan valid jika pertanyaan pada kuesioner mampu untuk mengungkapkan sesuatu yang akan diukur oleh kuesioner tersebut". Untuk melakukan uji validitas dilihat nilai signifikansi 2 tailed dibandingkan dengan 0,05 dengan dengan ketentuan:

1) Jika nilai signifikansi 2 talied < 0,05 , maka instrumen valid,

2) Jika nilai signifikansi 2 talied > 0,05 , maka instrumen tidak valid, 
Dari hasil pengujian diperoleh masing-masing item pernyataan pseluruh variabel diperoleh nilai signifikansi 2 tailed sebesar $0,000<0,05$, dengan demikian instrumen valid.

Uji berikutnya adalah uni reliabilitas. Model analisis uji reliabiltas yang digunakan dalam penelitian ini adalah model Alpha Cronbach. Menurut Ghozali (2013) berpendapat "reliabilitas merupakan alat untuk menguji kekonsistenan jawaban responden atas pertanyaan di kuesioner. Suatu kuesioner dikatakan reliabel jika jawaban seseorang terhadap pertanyaan adalah konsisten atau stabil dari waktu ke waktu". Dalam pengukurannya dilakukan dengan analisis Cronbach's Alpha. Ghozali (2013) mengklasifikasikan nilai Cronbach's Alpha sebagai berikut: 1) Jika nilai Cronbach's Alpha > 0,60, maka dinyatakan reliabel,

2) Jika nilai Cronbach's Alpha < 0,60, maka dinyatakan tidak reliabel,

Adapun hasil pengujiannya sebagai berikut:

Tabel 1. Hasil Pengujian Reliabilitas.

\begin{tabular}{|l|c|c|c|}
\hline \multicolumn{1}{|c|}{ Variabel } & Cronbach's Alpha & $\begin{array}{c}\text { Standar Kritis } \\
\text { Alpha }\end{array}$ & Keterangan \\
\hline Etos kerja (X1) & 0,638 & 0,600 & Reliabel \\
\hline Disiplin kerja (X2) & 0,645 & 0,600 & Reliabel \\
\hline Kinerja Pegawai (Y) & 0,612 & 0,600 & Reliabel \\
\hline
\end{tabular}

Berdasarkan hasil pengujuan di atas, Keseluruhan variabel etos kerja (X1), disiplin kerja (X2) diperoleh nilai cronbach alpha lebih besar dari 0,60. Dengan demikian dinyatakan reliabel.

\section{Uji Asumsi Klasik}

Uji asumsi klasik dimaksudkan untuk mengetahui ketepatan sebuah data. Menurut Singgih Santoso (2011) "Sebuah model regresi akan digunakan untuk melakukan peramalan, sebuah model yang baik adalah model dengan kesalahan peramalan yang seminimal mungkin". Karena itu, sebuah model sebelum digunakan seharusnya memenuhi beberapa asumsi, yang biasa disebut asumsi klasik. Dalam penelitian ini uji asumsi klasik yang digunakan adalah meliputi: Uji Normalitas, Uji Multikolinearitas, Uji Autokorelasi, dan Uji Heterokedastisitas. Adapun hasilnya sebagai berikut:

a. Uji Normalitas

Uji normalitas dilakukan untuk menguji apakah dalam model regresi, variabel dependen dan variabel independen berdistribusi normal atau berdistribusi tidak normal. Hasil uji normalitas dengan alat uji Kolmogorov-Smirnov Test, sebagai berikut:

Tabel 2 Hasil Normalitas Kolmogorov-Smirnov

Tests of Normality

Kolmogorov-Smirnov ${ }^{\text {a }} \quad$ Shapiro-Wilk

\begin{tabular}{lrr|r|r|r|r} 
& Statistic & \multicolumn{1}{c|}{ df } & \multicolumn{1}{c|}{ Sig. } & \multicolumn{1}{c|}{ Statistic } & \multicolumn{1}{c|}{ df } & \multicolumn{1}{c}{ Sig. } \\
\hline Kinerja Pegawai (Y) & .108 & 60 & .080 & .961 & 60 & .056 \\
\hline
\end{tabular}


*. This is a lower bound of the true significance.

a. Lilliefors Significance Correction

Berdasarkan hasil pengujian pada tabel diatas diperoleh nilai signifikansi 0,080 dimana nilai tersebut lebih besar dari nilai $\alpha=0,050$ atau $(0,080>0,050)$. Dengan demikian maka asumsi distribusi persamaan pada uji ini adalah normal.

b. Uji Multikonilieritas

Pengujian

mutlikolinearitas dilakukan

untuk meyakini bahwa antar variabel bebas tidak memiliki multikolinearitas atau tidak memiliki pengaruh korelasi antara variabel yang ditetapkan sebagai model dalam penelitian. Uji multikolinearitas dilakukan dengan melihat nilai Tolerance Value dan Variance Inflation Factor (VIF). Adapun hasil pengujiannya sebagai berikut:

Tabel 3. Hasil Uji Autokorelasi

Model Summary ${ }^{\mathrm{b}}$

\begin{tabular}{l|l} 
Adjusted R & Std. Error of \\
\hline Squre
\end{tabular}

\begin{tabular}{ll|r|rrrr} 
Model & $\mathrm{R}$ & \multicolumn{1}{c}{ R Square } & \multicolumn{1}{c}{ Square } & the Estimate & Durbin-Watson \\
\hline 1 & $.728^{\mathrm{a}}$ & .530 & .514 & 2.353 & 2.216 \\
\hline
\end{tabular}

a. Predictors: (Constant), Disiplin kerja (X2), Etos kerja (X1)

b. Dependent Variable: Kinerja Pegawai (Y)

Hasil pengujian pada tabel diatas diperoleh nilai Durbin-Watson sebesar 2,216 nilai tersebut berada diantara interval $1.550-2.460$. Dengan demikian model regresi dinyatakan tidak ada gangguan autokorelasi. c. Uji Heteroskesdasitas Pengujian heteroskedastisitas dimaksudkan untuk menguji apakah dalam sebuah model regresi terjadi ketidaksamaan varians residual. Hasil pengujiannya sebagai berikut:

Tabel 4. Hasil Uji Heteroskesdastisitas dengan Glejser Test Model

\begin{tabular}{|c|c|c|c|c|c|c|}
\hline \multirow{3}{*}{\multicolumn{2}{|c|}{ Model }} & \multicolumn{5}{|c|}{ Coefficients $^{\mathrm{a}}$} \\
\hline & & \multicolumn{2}{|c|}{$\begin{array}{l}\text { Unstandardized } \\
\text { Coefficients }\end{array}$} & \multirow{2}{*}{$\begin{array}{c}\text { Standardized } \\
\text { Coefficients } \\
\text { Beta }\end{array}$} & \multirow[b]{2}{*}{$\mathrm{t}$} & \multirow[b]{2}{*}{ Sig. } \\
\hline & & B & Std. Error & & & \\
\hline \multirow{3}{*}{1} & (Constant) & 5.592 & 2.150 & & 2.601 & .012 \\
\hline & Etos kerja (X1) & -.088 & .060 & -.230 & -1.460 & .150 \\
\hline & Disiplin kerja (X2) & -.014 & .061 & -.036 & -.226 & .822 \\
\hline
\end{tabular}

a. Dependent Variable: RES2

Hasil pengujian dengan menggunakan uji glejser diperoleh nilai Sig. > 0,05. Dengan demikian regression model tidak ada gangguan heteroskesdastisitas

\section{Analisis Deskriptif}

Pada pengujian ini digunakan untuk mengetahui skor minimum dan maksimum, mean score dan standar deviasi dari masing-masing variabel. Adapun 
hasilnya sebagai berikut:

Tabel 5. Hasil Analisis Descriptive Statistics Descriptive Statistics

\begin{tabular}{l|r|r|r|r|r} 
& N & \multicolumn{1}{|c|}{ Minimum } & Maximum & \multicolumn{1}{c|}{ Mean } & \multicolumn{1}{c}{ Std. Deviation } \\
\hline Etos kerja (X1) & 60 & 31 & 48 & 38.95 & 3.684 \\
\hline Disiplin kerja (X2) & 60 & 30 & 46 & 38.57 & 3.633 \\
\hline Kinerja Pegawai (Y) & 60 & 33 & 46 & 39.22 & 3.375 \\
\hline Valid N (listwise) & 60 & & & & \\
\hline
\end{tabular}

Etos kerja diperoleh varians minimum sebesar 31 dan varians maximum 48 dengan mean score sebesar 3,89 dengan standar deviasi 3,684.

Disiplin kerja diperoleh varians minimum sebesar 30 dan varians maximum 46 dengan mean score sebesar 3,85 dengan standar deviasi 3,633.

Kinerja pegawai diperoleh varians minimum sebesar 33 dan varians maximum 46 dengan mean score sebesar 3,92 dengan standar deviasi 3,375.

\section{Analisis Verifikatif}

Pada analisis ini dimaksudkan untuk mengetahui pengaruh variabel independen terhadap variabel dependen. Adapun hasil pengujian sebagai berikut:

a. Analisis Regresi Linier Berganda

Uji regresi ini

dimaksudkan untuk mengetahui perubahan variabel dependen jika variabel independen mengalami perubahan. Adapun hasil pengujiannya sebagai berikut:

Tabel 6. Hasil Pengujian Regresi Linier Berganda

\begin{tabular}{|c|c|c|c|c|c|c|}
\hline \multirow{3}{*}{\multicolumn{2}{|c|}{ Model }} & \multicolumn{3}{|c|}{ Coefficients $^{a}$} & \multirow[b]{3}{*}{$\mathrm{t}$} & \multirow[b]{3}{*}{ Sig. } \\
\hline & & \multicolumn{2}{|c|}{$\begin{array}{l}\text { Unstandardized } \\
\text { Coefficients }\end{array}$} & \multirow{2}{*}{$\begin{array}{c}\text { Standardized } \\
\text { Coefficients } \\
\text { Beta } \\
\end{array}$} & & \\
\hline & & $\mathrm{B}$ & Std. Error & & & \\
\hline 1 & (Constant) & 9.939 & 3.663 & & 2.713 & .009 \\
\hline & Etos kerja (X1) & .395 & .102 & .431 & 3.869 & .000 \\
\hline & Disiplin kerja (X2) & .360 & .104 & .387 & 3.475 & .001 \\
\hline
\end{tabular}

Berdasarkan hasil pengujian pada tabel di atas, diperoleh persamaan regresi $\mathrm{Y}=9,939+$ $0,395 \mathrm{X} 1+0,360 \mathrm{X} 2 . \quad$ Dari persamaan tersebut dijelaskan sebagai berikut:

1) Konstanta sebesar 9,939 diartikan jika etos kerja dan disiplin kerja tidak ada, maka telah terdapat nilai kinerja pegawai sebesar 9,939 point.

2) Koefisien regresi etos kerja sebesar 0,395, angka ini positif artinya setiap ada peningkatan etos kerja sebesar 0,395 maka kinerja pegawai juga akan mengalami peningkatan sebesar 0,395 point.

3) Koefisien regresi disiplin kerja sebesar 0,360, angka ini positif artinya setiap ada peningkatan disiplin kerja sebesar 0,360 maka kinerja pegawai juga akan mengalami peningkatan sebesar 0,360 point. 
b. Analisis Koefisien Korelasi

Analisis koefisien korelasi dimaksudkan untuk mengetahui tingkt kekuatan hubungan dari variabel

Tabel 7. Hasil Pengujian Koefisien Korelasi Etos kerja Terhadap Kinerja

Pegawai

Correlations $^{\mathbf{b}}$

\begin{tabular}{llr|r} 
& & $\begin{array}{c}\text { Etos kerja } \\
(\mathrm{X} 1)\end{array}$ & \multicolumn{1}{|c}{ Kinerja Pegawai (Y) } \\
\hline Etos kerja (X1) & Pearson Correlation & 1 & $.656^{* *}$ \\
\cline { 2 - 4 } & Sig. (2-tailed) & & .000 \\
\hline Kinerja Pegawai (Y) & Pearson Correlation & $.656^{* *}$ & 1 \\
\cline { 2 - 4 } & Sig. (2-tailed) & .000 & \\
\hline
\end{tabular}

Berdasarkan hasil pengujian diperoleh nilai korelasi sebesar 0,656 artinya Tabel 8. Hasil Pengujian Koefisien Korelasi Disiplin kerja Terhadap Kinerja

Pegawai.

\section{Correlations}

\begin{tabular}{llr|r} 
& & $\begin{array}{c}\text { Disiplin kerja } \\
(\mathrm{X} 2)\end{array}$ & Kinerja Pegawai (Y) \\
\hline Disiplin kerja (X2) & Pearson Correlation & 1 & $.638^{* *}$ \\
\cline { 2 - 4 } & Sig. (2-tailed) & & .000 \\
\hline Kinerja Pegawai (Y) & Pearson Correlation & $.638^{* *}$ & 1 \\
\cline { 2 - 4 } & Sig. (2-tailed) & .000 & \\
\hline
\end{tabular}

$\begin{array}{lrlr}\text { Berdasarkan } & \text { hasil } & \text { disiplin kerja memiliki } \\ \text { pengujian diperoleh } & \text { nilai } & \text { hubungan yang kuat terhadap } \\ \text { korelasi sebesar } 0,638 \text { artinya } & \text { kinerja pegawai. }\end{array}$

Tabel 9. Hasil Pengujian Koefisien Korelasi Etos kerja dan Disiplin kerja secara simultan Terhadap Kinerja Pegawai.

Model Summary

\begin{tabular}{|c|c|c|c|c|}
\hline Model & $\mathrm{R}$ & R Square & $\begin{array}{l}\text { Adjusted R } \\
\text { Square }\end{array}$ & $\begin{array}{l}\text { Std. Error of the } \\
\text { Estimate }\end{array}$ \\
\hline 1 & $.728^{\mathrm{a}}$ & .530 & .514 & 2.353 \\
\hline
\end{tabular}

Berdasarkan hasil pengujian diperoleh nilai korelasi sebesar 0,728 artinya etos kerja dan disiplin kerja secara simultan memiliki hubungan yang kuat terhadap kinerja pegawai.

c. Analisis Koefisien Determinasi Analisis koefisien etos kerja memiliki hubungan yang kuat terhadap kinerja pegawai. independen terhadap variabel maupun simultan. Adapun hasil pengujian sebagai berikut:

.


Tabel 11. Hasil Pengujian Koefisien Determinasi Etos kerja Terhadap Kinerja Pegawai.

Model Summary

\begin{tabular}{|c|c|c|c|c|}
\hline Model & $\mathrm{R}$ & R Square & $\begin{array}{l}\text { Adjusted R } \\
\text { Square }\end{array}$ & $\begin{array}{l}\text { Std. Error of the } \\
\text { Estimate }\end{array}$ \\
\hline 1 & $.656^{\mathrm{a}}$ & .431 & .421 & 2.568 \\
\hline
\end{tabular}

Berdasarkan hasil

pengujian diperoleh nilai determinasi sebesar 0,431

artinya etos kerja memiliki

kontribusi pengaruh sebesar $43,1 \%$ terhadap kinerja

Tabel 12. Hasil Pengujian Koefisien Determinasi Disiplin kerja Terhadap

Kinerja Pegawai

Model Summary

\begin{tabular}{|c|c|c|c|c|}
\hline Model & $\mathrm{R}$ & R Square & $\begin{array}{l}\text { Adjusted R } \\
\text { Square }\end{array}$ & $\begin{array}{l}\text { Std. Error of the } \\
\text { Estimate }\end{array}$ \\
\hline 1 & $.638^{\mathrm{a}}$ & .407 & .397 & 2.621 \\
\hline
\end{tabular}

Berdasarkan hasil pengujian diperoleh nilai determinasi sebesar 0,407 artinya disiplin kerja memiliki

kontribusi pengaruh sebesar $40,7 \%$ terhadap kinerja pegawai.

Tabel 13. Hasil Pengujian Koefisien Determinasi Etos kerja dan Disiplin kerja Terhadap Kinerja Pegawai.

Model Summary

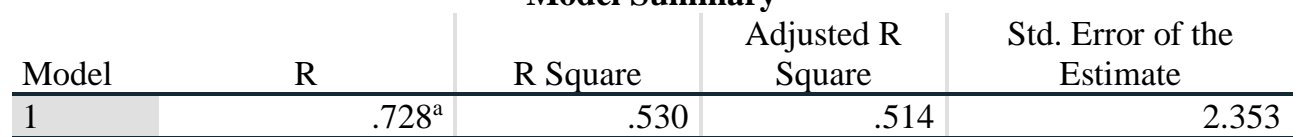

a. Predictors: (Constant), Disiplin kerja (X2), Etos kerja (X1)

Berdasarkan hasil

pengujian diperoleh nilai

determinasi sebesar 0,530

artinya etos kerja dan disiplin

kerja secara simultan memiliki

kontribusi pengaruh sebesar $53,0 \%$ terhadap kinerja pegawai, sedangkan sisanya sebesar 47,0\% dipengaruhi faktor lain. d. Uji Hipotesis

Uji hipotesis Parsial (Uji t)

Pengujian hipotesis dengan uji $\mathrm{t}$ digunakan untuk mengetahui hipotesis parsial mana yang diterima.

Hipotesis pertama:

Terdapat pengaruh yang signifikan antara etos kerja terhadap kinerja pegawai.

Tabel 14. Hasil Uji Hipotesis Etos kerja Terhadap Kinerja Pegawai.

Coefficients $^{\mathrm{a}}$

Unstandardized

Coefficients

Standardized

Coefficients

\begin{tabular}{|c|c|c|c|c|c|}
\hline Model & $\mathrm{B}$ & Std. Error & Beta & $\mathrm{t}$ & Sig. \\
\hline $1 \quad$ (Constant) & 15.791 & 3.550 & & 4.448 & .000 \\
\hline Etos kerja (X1) & .601 & .091 & .656 & 6.628 & .000 \\
\hline
\end{tabular}


a. Dependent Variable: Kinerja Pegawai (Y)

Berdasarkan hasil pengujian pada tabel di atas, diperoleh nilai t hitung $>\mathrm{t}$ tabel atau $(6,628>2,002)$, dengan demikian hipotesis pertama

Tabel 15. Hasil Uji Hipotesis Disiplin kerja Terhadap Kinerja Pegawai.

\section{Coefficients ${ }^{\mathrm{a}}$}

\begin{tabular}{|c|c|c|c|c|c|}
\hline \multirow[b]{2}{*}{ Model } & \multicolumn{2}{|c|}{$\begin{array}{l}\text { Unstandardized } \\
\text { Coefficients }\end{array}$} & \multirow{2}{*}{$\begin{array}{c}\text { Standardized } \\
\text { Coefficients } \\
\text { Beta } \\
\end{array}$} & \multirow[b]{2}{*}{$\mathrm{t}$} & \multirow[b]{2}{*}{ Sig. } \\
\hline & $\mathrm{B}$ & Std. Error & & & \\
\hline 1 (Constant) & 16.354 & 3.638 & & 4.495 & .000 \\
\hline Disiplin kerja (X2) & .593 & .094 & .638 & 6.311 & .000 \\
\hline
\end{tabular}

a. Dependent Variable: Kinerja Pegawai (Y)

Berdasarkan hasil pengujian pada tabel di atas, diperoleh nilai $\mathrm{t}$ hitung $>\mathrm{t}$ tabel atau $(6,311>2,002)$, dengan demikian hipotesis kedua yang diajukan bahwa terdapat pengaruh yang signifikan atara disiplin kerja terhadap kinerja pegawai diterima.

Tabel 16. Hasil Uji Hipotesis Etos kerja dan Disiplin kerja Terhadap

Kinerja Pegawai

ANOVA ${ }^{\mathrm{a}}$

\begin{tabular}{ll|r|r|r|r|r} 
Model & & Sum of Squares & df & Mean Square & F & \multicolumn{1}{c}{ Sig. } \\
\hline \multirow{2}{*}{1} & Regression & 356.549 & 2 & 178.274 & 32.194 & $.000^{\mathrm{b}}$ \\
\cline { 2 - 7 } & Residual & 315.635 & 57 & 5.537 & & \\
\cline { 2 - 7 } & Total & 672.183 & 59 & & & \\
\hline
\end{tabular}

Berdasarkan hasil pengujian pada tabel di atas, diperoleh nilai $\mathrm{F}$ hitung $>\mathrm{F}$ tabel atau $(32,194>2,770)$, dengan demikian hipotesis ketiga yang diajukan bahwa terdapat pengaruh yang signifikan atara etos kerja dan disiplin kerja terhadap kinerja pegawai diterima.

PEMBAHASAN

HASIL

PENELITIAN

1. Pengaruh Etos Kerja Terhadap Kinerja Pegawai

\section{Uji Hipotesis Simultan (Uji F)}

Pengujian hipotesis dengan uji $\mathrm{F}$ digunakan untuk mengetahui hipotesis simultan yang mana yang diterima. Hipotesis ketiga Terdapat pengaruh yang signifikan antara etos kerja dan disiplin kerja terhadap kinerja pegawai.

yang diajukan bahwa terdapat etos kerja terhadap kinerja pegawai diterima. 
2. Pengaruh Disiplin kerja Terhadap Kinerja Pegawai

Dari hasil analisis diperoleh variabel disiplin kerja berpengaruh signifikan terhadap kinerja pegawai dengan nilai korelasi sebesar 0,638 artinya kedua variabel memiliki hubungan yang kuat dengan kontribusi pengaruh sebesar 40,7\%. Pengujian hipotesis diperoleh nilai t hitung > $t$ tabel atau $(6,311>2,002)$. Dengan demikian hipotesis kedua yang diajukan bahwa terdapat berpengaruh signifikan antara disiplin kerja terhadap kinerja pegawai diterima.

3. Pengaruh Etos kerja dan Disiplin kerja Terhadap Kinerja Pegawai

Dari hasil analisis diperoleh variabel etos kerja dan disiplin kerja berpengaruh signifikan terhadap kinerja pegawai dengan diperoleh persamaan regresi $\mathrm{Y}=$ $9,939+0,395 \times 1+0,360 \times 2$, nilai korelasi sebesar 0,728 artinya kedua variabel memiliki hubungan yang kuat dengan kontribusi pengaruh sebesar $53,0 \%$ sedangkan sisanya sebesar $47,0 \%$ dipengaruhi faktor lain. Pengujian hipotesis diperoleh nilai $\mathrm{F}$ hitung > $F$ tabel atau (32,194 > 2,770). Dengan demikian hipotesis ketiga yang diajukan bahwa terdapat berpengaruh signifikan antara etos kerja dan disiplin kerja terhadap kinerja pegawai diterima.

\section{KESIMPULAN DAN SARAN}

\section{A. Kesimpulan}

1. Etos kerja berpengaruh signifikan terhadap kinerja pegawai nilai korelasi sebesar 0,656 atau kuat dengan kontribusi pengaruh sebesar $43,1 \%$. Uji hipotesis diperoleh nilai $\mathrm{t}$ hitung $>\mathrm{t}$ tabel atau $(6,628>2,002)$. Dengan demikian terdapat pengaruh yang signifikan antara etos kerja terhadap kinerja pegawai pada Dinas Kehutanan dan Perkebunan Kota Bogor.

2. Disiplin kerja berpengaruh signifikan terhadap kinerja pegawai dengan nilai korelasi sebesar 0,638 atau kuat dengan kontribusi pengaruh sebesar $40,7 \%$. Uji hipotesis diperoleh nilai $\mathrm{t}$ hitung $>\mathrm{t}$ tabel atau $(6,311>2,002)$. Dengan demikian terdapat pengaruh yang signifikan antara disiplin kerja terhadap kinerja pegawai pada Dinas Kehutanan dan Perkebunan Kota Bogor.

3. Etos kerja dan disiplin kerja berpengaruh signifikan terhadap kinerja pegawai dengan nilai korelasi sebesar 0,728 atau kuat dengan kontribusi pengaruh sebesar $53,0 \%$ sedangkan sisanya sebesar 47,0\% dipengaruhi faktor lain. Uji hipotesis diperoleh nilai $\mathrm{F}$ hitung $>\mathrm{F}$ tabel atau $(32,194>2,770)$. Dengan demikian terdapat pengaruh yang signifikan antara etos kerja dan disiplin kerja secara simultan terhadap kinerja pegawai pada Dinas Kehutanan dan Perkebunan Kota Bogor.

\section{B. Saran}

1. Etos kerja juga, disarankan tetap dipertahakan kualitasnya dengan mendorong pegawai untuk selalu bekerja dengan 
tuntas, bekerja penuh kesadaran dan bekerja dengan suka cita

2. Disiplin kerja yang ada selama ini juga, sebaiknya tetap dipertahankan dengan mendorong pegawai, agar dengan peraturan yang ditetapkan menjadikannya termotivasi untuk selalu menyelesaikan tugas yang diberikan pimipinan.

3. Kinerja pegawai dapat ditingkatkan dengan memberdayakan pegawai dengan menegakkan peraturan yang baik dan pemberian disiplin kerja yang lebih inten lagi.

\section{DAFTAR PUSTAKA}

Algifari. (2015). Analisis Regresi untuk Bisnis dan Ekonomi. Yogyakarta: BPFE.

Amran, (2009), Pengaruh Disiplin Kerja Terhadap KInerja Pegawai Kantor Departemen Sosial Kabupaten Gorontalo, Jurnal Ichsan Gorontalo, Vol 4, No 2. Hal. 43-55

Arikunto, Suharsimi (2014). Prosedur Penelitian Suatu Pendekatan Praktek. Jakarta: Rineka Cipta.

Asmara Hendra Komara, (2009), Pengaruh Strategi Organisasi dan Motivasi Kerja Terhadap Kinerja Pegawai Dinas Kimpraswil Provinsi Riau, Jurnal Tepak Manjemen Bisnis, Vol 1, No1.

Daulay, Nurul Kausar. (2011). Pengaruh Etos Kerja, Kepuasan Kerja Dan Motivasi Berprestasi Terhadap Kinerja Pegawai Instalasi Pengolahan Air PDAM Tirtanadi Provinsi
Sumatera Utara. Tesis. Sekolah

Pascasarjana Universitas

Sumatera Utara Medan.

Edi Sutrisno (2016). Manajemen Sumber Daya Manusia. Jakarta: Prenadamedia Group.

Freed Luthans (2016) Organizational Behavior, New York: McGrawHill.

Gerry Dessler (2016) Human Resources Management, Prenticehall, London: International Inc.

Handoko (2016) Manajemen Personalia dan Sumberdaya Manusia. Yogyakarta: BPFE.

Hasibuan (2016) Manajemen Sumber Daya Manusia. Jakarta: Haji Masagung.

Henry Simamora (2005), Manajemen Sumber Daya Manusia, STIE YKPN Bandung.

Imam Ghozali (2017). Aplikasi Analisis Multivariate Dengan Program SPSS. Edisi Kelima. Semarang: Badan Penerbit Undip.

Mangkunegara, (2011). Manajemen Sumber Daya Manusia Perusahaan, Remaja Rosdakarya, Bandung.

Riduwan. (2002). Skala Pengukuran Variabel-Variabel Penelitian. Alpabeta. Bandung

Sinamo, Jansen H. (2011). 8 Etos Kerja Profesional Navigator Anda Menuju Sukses. Jakarta: PT Spirit Mahardika.

Rivai Veithzal (2015) Manajemen Sumber Daya Manusia Untuk Perusahaan. Jakarta: PT Raja Grafindo Persada.

Rozi, A., Agustin, F., Hindriari, R., Rostikawati, D., \& Akbar, I. R. (2020). The Effect Of Leadership On Employee 
Performance at PT. Stella

Satindo In Jakarta. HUMANIS

(Humanities, Management and

Science Proceedings), 1(1).

Santoso, Singgih (2015). Menguasai

Statistik Multivariat. Jakarta:

PT Elex Media Komputindo.

Sarwani, S., Akbar, I. R., Handoko,

A. L., \& Ilham, D. (2020).

Pengaruh Pelatihan dan

Motivasi terhadap

Produktivitas Kerja Karyawan pada PT. Lion Mentari Airlines Bandara Internasional Soekarno Hatta Cengkareng. Jurnal Ilmu Komputer dan Bisnis, 11(2a), 91-100.

Sedarmayanti (2016) Manajemen Sumber Daya Manusia, Reformasi Birokrasi dan
Manajemen Pegawai Negeri Sipil, Cetakan Kelima, Bandung: PT Refika Aditama.

Siagian, S (2007). Manajemen Sumber Daya Manusia. Jakarta: Bumi Aksara.

Sinamo, J. (2011). Delapan Etos Kerja Profesional. Jakarta: Institut

Sinamo, Jansen. (2005). Delapan Etos Kerja Professional. Institut Mahardika. Jakarta Soejono, (1997). Sistem dan Prosedur Kerja. Jakarta: Bumi Aksara.

Sudjana (2014) Metode Statistika", Bandung: Tarsido.

Sugiyono (2017), Metode Penelitian Administrasi: dilengkapi dengan Metode $R \& D$. Bandung: Alfabeta. 